\title{
El CABALLERO DE LO ALTO
}

Un caballero muy alto va por corceles sin freno, lleva su luz en la frente que ciñe a la noche estrecha.

Es que en lo negro hay un vuelo que es tan veloz como un sueño y sed audaz que despierta en que se pierde la tierra.

Con rojo enciende fantasmas en oro conquista el fuego; sus dedos, codicias ágiles, desangran tu vida al vuelo.

No hay nadie en su gran palacio que no sea muro o sea piedra o cuadros que sueñan ávidos con el color de recuerdos.

Su dama sepulta en mármol no se le apaga en encierro ni en joyas que le han robado su libertad de ágil cielo.

Con su gran luz en la frente se le ha perdido la estrella. Un caballero va en lo alto por corazones sin freno. 